\title{
To Examine the Transformation of Personal Image Management in The Context of Bourdieu on Social Media
}

\author{
Tan H. ${ }^{1}$ \\ ${ }^{1}$ Hakan TAN, İstanbul Aydın University, (Turkey) \\ e-mail: hakantan@stu.aydin.edu.tr
}

\begin{abstract}
Human beings have a tendency to adapt to the society in which they live. The manifestation of this adaptation is explained by social psychology over the concepts of compliance, identification and internalization. Through this adaptation, human beings "be in harmony" with other people in their lives. However, they also need to "differentiate" themselves in order to exist freely. The purpose of this "differentiation" is to gain a higher rank in one's society and demonstrate personal roles. In his "field theory" Pierre Bourdieu refers to the structures wherein economic, social and symbolic capital, which create this distinction, are comprised. According to Bourdieu, the concept of capital is "a tool or an instrument of social distinction". And field is what structures "habitus". Bourdieu describes habitus as "the whole of permanent tendencies/conveniences wherein socialized past experiences are merged together". Bourdieou suggests that a person assumes their role within the context of the factors included in their field on the "stage". This is also not a representation; this is the person's position. The person fulfils their role as much as their human capital and tendencies allow within the context of "field". As far as the study's context is concerned, social media is a stage and people are actors who play the roles assigned to them. And the actors demonstrate and fulfil their roles on the stage. Social media is a stage which enables people to express their personalities and also helps form, develop and feed those personalities. People desire to "differentiate", "become famous", "obtain high social ranks", "earn money using social ranks" and separate themselves from those "they are in harmony with". In order to gain the desired, ideal and desirable image, the person should use the technology provided by Smart Mobile Phone, Applications and social media. Using these technologies, the person also employs personal image management to have an ideal and a generally desired image. With the concept of "habits", Bourdieu refers to an earned position, how one gets there, who gets there, habits and processes. The paper aims to investigate the properties of new and social media. In addition, it aims to investigate the change, development and transformation of these characteristics into the life practices of people, through the context of Bourdieu's "field theory" and "habitus" context. The article is written in Istanbul Aydın University under the dissertation titled "Transformation of Personal and Brand Image Management in Social Media". In this research, descriptive research, focus group method and survey technics are used which are the research methods and applications of communication science.
\end{abstract}

Keywords: Bourdieu, Habitus, Field Theory, Social Media, Image, Self, Image Management.

\section{Introduction}

Since established social sciences have been concerned with concepts such as division of labour, role, status, position and disintegration. What is prominent in Herbert Spencer is "organism", in Durkheim it's anomie, division of labour, social substructures and superstructures and the transitions between them, in Talcott Parsons its the concepts of actor, roles, information and cybernetics and the abbreviation of AGIL (Tan, 2019a; 191). The abbreviation AGIL consists of the first letters of the concepts of "adaptation", "goal attainment", "integration" and "latency" (Mattelart, 2004; Güngör, 2013). According to Parsons, a person is an actor who plays their roles and pursues goals within society. In the works of Pierre Bourdieu, the theories and concepts of "field theory" and "habitus" stand out and Bourdieu agrees with the opinions of Durkheim and Parsons. Bourdieu also contributes to these views. For instance, Bourdieu wants to add "positioning" to prominent concepts in Durkheim's works. Bourdieu, with the concept of positioning, says that "... by understanding the life practices of people according to their occupied position in social space, we can demonstrate how they are classified and 
what kind of a 'class' they are members of" (2016b: 93). Bourdieu stresses that if we investigate how people get to positions in their lives, how they move between positions and the effects of their position on life practices, then we can find the meaning of people's transitions between social substructures and superstructures and their spatial practices. "Talcott Parsons iterates that a social action is a behaviour which "aims for a purpose", "includes adaptation", "is motivated" and "directed by symbolic processes (...) that is, it gains meaning when we admit that the social actor is in a behavioural tendency, and that "meaning" is an indispensable category for sociology" (Reynaud and Bourdieu, 2014: 141). Bourdieu accepts the person as a social actor. And according to him there is an orientation behind one's behaviour. He explains that the "meaning" behind this orientation occurs in the relationship between the person's purpose, adaptation, motivation and symbolic processes.

Bourdieu says that a person has a position in society and explains the formation of this position by the "field theory". At the centre of the field theory lies the concept of capital. According to Bourdieu, "the concept of capital is the tool or instrument of social distinction "(Yarcl, 2014: 130). And Bourdieu says that "the field configures the habitus" (Bourdieu and Wacquant, 2016: 118). Habitus is explained as "A whole of (a person's) permanent tendencies /conveniences in which a person's past socialized experiences are merged into one another" (Bourdieu, 2015: 234). Bourdieu refers to the structures in which economic, social, cultural and symbolic capital are formed in field theory. With its habitus concept, Bourdieu refers to past experiences, knowledge stock and past traditions that shape the present in the society of the individual, and the permanent tendencies associated with integration. Bourdieu suggests that a person assumes their role within the context of the factors included in their field on the "stage". This is also not a representation; this is the person's position. The person represents the role of the person in the concept of space and the position they acquired within the framework of the sum of the capitals in the concept of space. Social media is a stage in the context of research.

A person's desire to socialize, supported by technology, acknowledged McLuhan's "global village" concept and therefore went on to create social media platforms. Penetration to social media is increasing rapidly. People who were in reader, listener and watcher positions in the traditional media now can take place in media that is the stage, thanks to the interactive properties of the new and social media by participating and sharing. Communication in social media is transitioning from a mediated type of communication into an unmediated type. Thus, the definition and characteristics of communication take place in social media. The fact that communication is defined is in social media platforms leads us to consider the concepts of self and image by studying just how the self is presented or demonstrated or acknowledged in a fashion very similar to unmediated communication. Image is the imagination that occurs as a result of the interaction and life practices between the person and others and between people and objects. The self is formed as a result of the interaction of the individual with the others and the objects in the social structure and the presentation of the self is accepted as the image of the person. As a result of people's perception and acceptance of communication in social media as face-to-face communication, communication on the social media stage is transformed into an unmediated type of interaction. This transforms the presentation of self (image), the relationship of self with others, impression management and personal image management. Social media is a stage in the context of research. People are actors who play their roles. And the actors demonstrate and fulfil their roles on the stage. Social media is a stage which enables people to express their personalities and also helps form, develop and feed those personalities. People enter the social media stage because social media helps people to express their selves, help the self to form and develop and interact with others.

The first scientific work on image management is Erving Goffman's "The Presentation of Self in Everyday Life". Moving on from William Shakespeare's saying "the world is a theatre", Goffman approaches the presentation of self, in other words, image, by conceptualizing it as a dramaturgical stage play. In his work titled "The Presentation of Self in Everyday Life" (1978, 2014), Goffman accepts persons as actors in daily life and explains that very similar to a theatre, people assume their roles in a stage which likewise consists of a set, showcase and decor, carrying out an impression and image management. According to Bourdieu, the person is positioned and classified by the social, cultural, economic and symbolic capital they possess or produce. Referring to Goffman, Bourdieu explains that the capital factors within the field concept "directly or indirectly manages representations, and as worded by Goffman, 'self-representation' strategies, that is the projection of position onto the stage, of each actor, using the position advantage granted by the class structure which can be read 
through various material indicators, and using the position granted by collective classification" (2014a: 196). On the other hand, Bourdieu states that all forms of recognition and perception that make up the symbolic capital take place in a field of struggle. And according to Bourdieu" This struggle cannot be reduced to the Goffmanian struggle, which is the struggle to present one's own advantageous representation" (2016: 286). Bourdieu explains that a person struggles in a field of power and gains position with the symbolic capital that they produce; "The symbolic capital saves the person from insignificance - which both expresses the lack of importance and meaning "(2016: 287). Persons do not want to present their self with the sum of the symbolic capitals they produce. People desire to "differentiate", "become famous", "obtain high social ranks", "earn money using social ranks" and separate themselves from those "they are in harmony with". In other words, they want to "exist". According to Bourdieu "they exist, and will continue to exist, because they occupy relative positions in a space of relations which is the real source of individual and group behaviour" (2015: 49). And the reason why people join the symbolic power game is explained as follows:"In short, they accept this game due to a somewhat important claim of 'existing' (Bourdieu, 2015: 67). According to Bourdieu position equals to existence and existence equals to position. In this case, if the person has no position, there is no presence of them. In Bourdieu's words, the symbolic power that people want to achieve is; The power on others -which power is rooted in others, the looks, perceptions and appreciations of others "(Bourdieu, 2016a: 287). Bourdieu emphasizes the images and content a person shares on their social media platform, and the importance of admiration, positive comments, the number of likes from other people on these images and content, as well as having a large number of followers on the person's page. In order to gain the desired, ideal and desirable image, the person should use the technology provided by Smart Mobile Phone, Applications and social media. Once the person has the desired, ideal and desirable image, he expects other people to appreciate and positively comment on the images and contents he shares. In the event that this happens, people can obtain a symbolic power with the spreading power of social media. People do personal image management in the social media stage.

\section{Image Concept and Management}

Image has communicative, auditory, conceptual, visual, mythological, historical, cultural, social and religious dimensions. For example, historical people, events and places can be transformed into images with paintings, sculptures and designs. Culture consists of images. Although visual image is mentioned in the concept of image, eye, vision and visuality are more prominent aspects. In his work titled "Visual Thinking", Arnheim emphasizes the fact that "visual perception is the same as visual thinking" (2015: 28). For example, Gombrich explains the place of the power of the visual image in the history through the words of Pope Gregory the Great," What letters are to the literate, pictures are that to the illiterate "(2015: 154). Pope Gregorius the Great emphasizes that people can understand the contents of the transponder / sender / encoder with the visual image. Images, symbols and indicators facilitate the process of communication and learning. In addition, the biggest difference between human beings and animals is to possess the ability to produce, understand and use symbols. And as technology evolves and the use of technological tools increases, so do that of images, symbols and indicators. Today, whether they are of mechanical, analogue, digital (analogue or digital photograph, video) or natural (body, nature) character, visual images are the daily life source of ideas, feelings, excitements, information and the power of stimulation.

Image is a representation of an externally perceived object, reflected on consciousness. According to the Turkish Language Institution, image is appearance and impression. In his work titled "Iconology: Image, Text, Ideology", American researcher W.J. Thomas Mitchel evaluates and classifies image/images under five categories: "a) Graphic, b) Optic, c) Perceptual, d) Mental, e) Verbal" (2005: 12) According to Mitchel, people visualize objects through graphic images (painting / sculpture / design) and symbols; explain the reflections of people on mirrors and cameras using optical images; and from perceptual images, they evaluate and classify the images that one obtains, through the sensory organs, about himself, other people and the objects. In addition, Mitchell describes the cognitive visuals which instantaneously form in the layers of self perception during dreams at night or when we are awake, while touching upon verbal images in terms of the appearances of mental images formed by acoustic images in our personality and consciousness. According to Mitchel, images are not just symbols, indicators and signs. Images have visuals that turn into an independent existence in the historical process and vital practices for individuals. In other words, the relationships between image, graphical, optical, perceptual, mental and oral images and historical, religious, mythical, social and 
cultural processes, and the relationships between the person and other persons and between the person and objects, form within the domain of interaction, meaning, interpretation and experience. "For example, apple is a word (mental and auditory image). It also refers to an object. If we draw an icon it becomes a symbol, but in our mind, the apple as an image now becomes different. The reality ends, it detects its place, and then gets replaced with images, interpretations, associations, myths and meanings. Apple is green, yellow and red. Even these colours throw us from here to there. Apple is sweet, sour and juicy. Apple is hard and sometimes soft. It is small and large. It is the forbidden fruit because it caused Adam and Eve to be cast away from Eden. It is historical, religious, mythological. Has it not scientifically caused the presence of gravity? On the other hand, Apple is a brand. "Apple" in our language. Give me an Apple? It is a fruit or brand according to its context in America. In Turkey, it is a brand. Aren't the first things that come to our minds, the above associations, images and myths? Apple's icon, the logo, is a bitten apple (same as apples in heaven). When we say Apple, associations, perceptions and images such as Steve Jobs, technology, communication, the most valuable, most admired, most technological brand come to mind (Tan, 2017a). Thus, image is the imagination that occurs as a result of the historical process, interaction and life practices between the person and others and between people and objects. According to thinkers "image is a set of meanings defined, remembered and associated with the target audience about a concept, object or person. It is the imagination resulting from the interaction between an individual's observations, experiences, beliefs, feelings and ideas" (Dowling, 1986: 109, quoted by Bulduklu, 2015: 22). According to C.G. Jung "image is a thought on object" (Okay, 2012: 211). Dowling and C.G. Jung explain that the image is formed in historical, religious, mythical, social, intellectual, cultural meaning and interpretation, and personal and social interactions and experiences.

According to literature researches on image management, the first image management study is the "Fugger Letters" which belongs to the Fugger family. The Fugger family created the symbols and images specific to the Fugger family using "Fugger Letters" ait and thus possessed symbols and images of their own, published a newspaper bearing their own symbols and images, and wanted to create an international communication system with newspapers and letters. Since then, communication applications and tools (media) have been transforming society, economy, culture and image management. Image management, according to Akgöz, "aims to create a positive image, to reinforce and improve the image of individuals and masses who do not have the idea or idea about a subject" (2014: 19). Bulduklu describes image management as "expresses the behavioural strategies used by individuals to create desirable social images or identities, and aims to achieve success by creating an impression in favour of one person or another over others." Thus, it aims to control the behaviours of others" (2015: 37). Özdemirci says, "The concept of image management is directly related to consumer psychology. Being different and expressing oneself is one of the most basic needs of a human being" (2014: 2). Using image management, both individuals and brands apply strategies aimed at directing, classifying and limiting the thoughts and behaviours of people in order to attain the ideal positive image in the eyes of their target audience.

\section{Personal Image Management}

In the past, personal image was perceived, seen, interpreted and implemented by individuals and administrations as a valuable method. For example, according to Dinçer "image and noticability in career development now works nine times more than skill" (2001: 5). Criticising this, Fromm suggests that people value the concepts of personality/self that which become special and ideal to the society they identify with, saying "People no more work for their own lives and happiness, they work to market themselves in the best way. (...) The main principle is the promise which is 'I am exactly like how you want to own me' (2015:186). Barthes supports Fromm with the following sentences: "The Western show is humanly shaped (...) A sound here, a look there, a stance over there were all eroticized as parts of the body, as fetishes" (2016: 63). On the other hand, in today's business life and management, it can be observed that the image and personal image are very important in social media and daily life practices we present ourselves. Polat and Arslan, for example, referred to KerDinçer (2001), citing the importance of personal image: "makes people feel good; increases selfconfidence of the person and thus increases his performance." It also motivates the person to be better; the person is more effective and successful; the person communicates more effectively and improves the relationship of the person with others" (2015: 29). Three elements stand out in the personal image: "a) self image: how we see ourselves, b) the perceived image: how others see us, c) the desired / ideal image: how we want to see ourselves show ourselves to others" (Çakır, 2015: 19; 
Dinçer, 2001: 5). Personal image consists of who a person is, who they want to be, what treats they possess, what treats they want to possess and how they desire to perceive themselves within a scale that goes from their present image to their ideal image, and a person's desire to showcase this to themselves and other people to create impressions. According to Kabadayı, communication is in fact personal image management. Kabadayı suggests that the colours, fabrics, accessories, sounds, body language, gestures, mimics and visuals in communication, in other words, a person's outlook, communication style, communicative behaviours and stance are all aspects of a personal image management that is aimed at manipulating how a person would like themselves to be perceived by others (2011). Sampson says "the first visual we notice is the image" and referring to the research of Albert Mehrabian, social psychologist, reiterates that $55 \%$ of the first impression consists of appearance, 38\% consists of sounds/voice and only $7 \%$ consists of content, therefore supporting Mehrabian's views" (1995: 17-27). Çakır explains the reason of visual aspects "dominance in the personal image with the fact that the nerves between the eyes and the brain are about 20 times stronger than the nerves between the ears and the brain" (2015: 23). Eyes, seeing, visual images, visual indicators and visuality, the attributes of a person's body can allow easier perception of visual images and indicators and therefore lead for these visual images to be more important for people.

Sampson describes the elements of personal image management as: "appearance", "body language", "reputation ", "communication style" and "stance" as in Figure 1. The physical features of the person, appearance of clothing and clothing are prominent. Body language gesture, mimics, used set, decor, stage; communication practices and means of communication; the person's identity, personality, character and self in terms of stance; in the case of reputation, whether one's experiences are easily recognized by others and their qualities. Using new media tools, people can showcase in social media platforms their physical attributes, clothes, the locations they experience, the activities they participate, body language which is an aspect of personal image, communication style, stance and convey the impression they desire to get across, in attempts to gain reputation. Personal image management is the efforts of a person to present, to themselves and to other people, an ideal image of themselves which they attempt to create in the stage they realize their life practices, using the tools, social media platforms and technical means provided by software applications as part of a strategy and impression management in terms of personal image management. In addition to these, personal image is to know and develop one's personality, including life images into one's personality and the efforts to present one's personality.

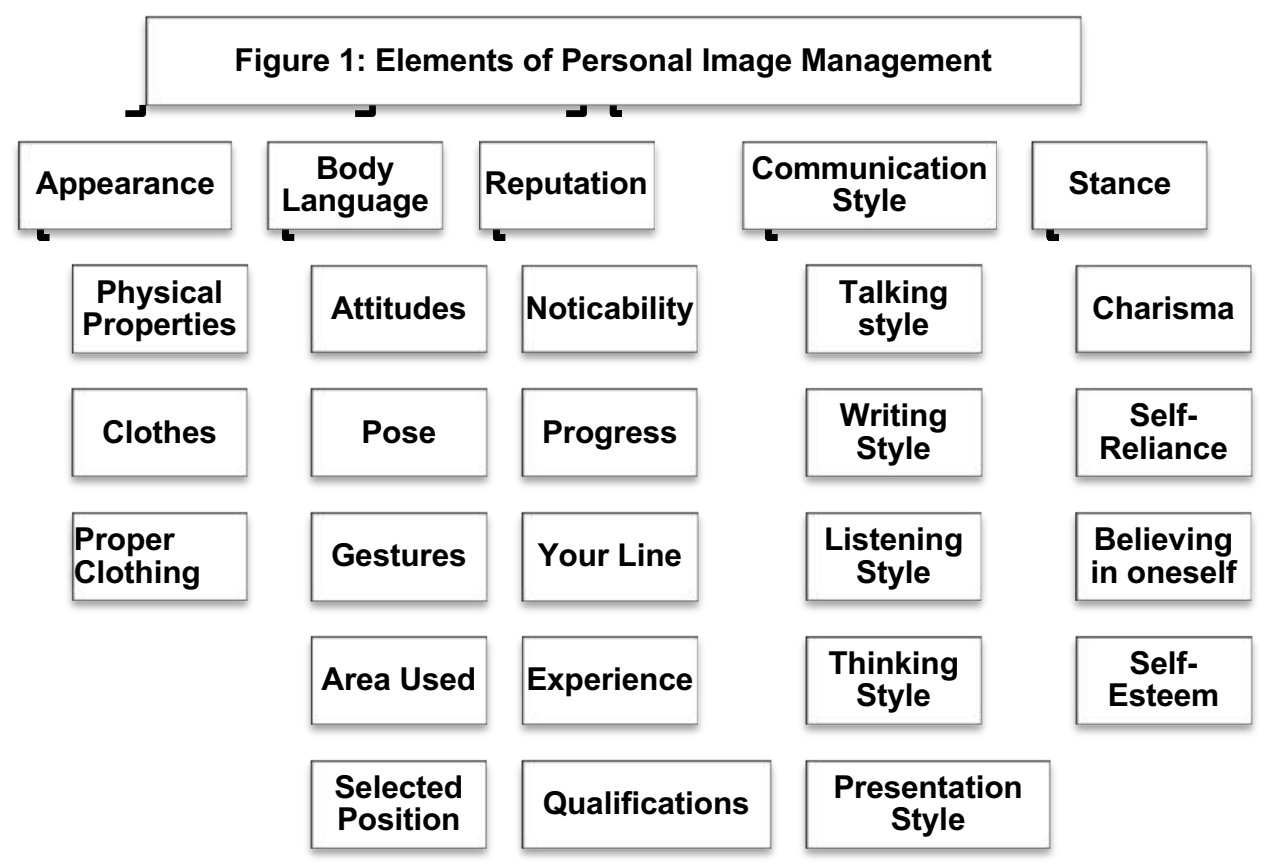

(Source: Sampson, 1995: 21) 


\section{Social Media, Self Concepts and Their Relationship}

People's desire to socialize and technology allowing it gave way to McLuhan's concept of "global village", therefore creating social media platforms. "Social media can have distinctive features such as bi-directional, interactive, participatory and sharing. The characteristics that distinguish social media from traditional media are being bi-directional, interactive, participatory and allowing for sharing. Thus, the definition and characteristics of communication take place in social media" (Tan, 2017d). According to thinkers "Social media is an expandable media and it creates a participatory culture too" (Jenkins, Ford and Green, 2013); "Social media and Web 2.0 is users' ability to produce content in media" (Kaplan and Haenlein, 2009: 60); "Social media is explained as the online sources of information that require memberships, which sources consist of words-of-mouth about topics created by users, as well as personalities, services, products and brands" (Mangold and Faulds, 2009: 358); "Social media is targeted, personal, interactive, participant, direct, timely, content produced, can be contacted with the consumer, has the capacity to share socially" (Kotler and Armstrong, 2016: 545546). According to thinkers' definitions, social media "is a media where people and brands can produce content; people can interact with and respond to other people and the content produced by other people, share this content and therefore where people can be active contrary to traditional media, and in a general sense where people can be both encoders and decoders. Also, according to thinkers, social media is a stage where communication productions can spread, a collaborative and participatory culture is created and people's life practices come to life. According to O'Reilly (2005), "Web 2.0 is not technology, Web 2.0 is an attitude" (Hinton and Hjorth, 2013: 16). According to social psychology, elements of attitude are cognitive, emotional and behavioural; "a tendency of the individual to organize a response based on his / her experience, knowledge, emotions and motivation against any object, or any subject or event around him / her "(Inceoğlu, 2011: 22-23). With the cognitive, emotional and behavioural dimensions of Web 2.0, Tim O'Reilly draws attention to the relationship that person has with himself and his relationship with the tool and his experiences in this relationship with Web 2.0. The article examines how the tendencies in the stage presented by the presentation of the self when they are the subject in their experiences, and the relationship between the individuals' self and the stage are examined.

Social media is also a stage. Readers, listeners and watchers in traditional media can now take their own places in the new media (stage), thanks to new and social media's interactive, participatory and sharing attributes. It is as if mediated communication (media) transforms into an unmediated communication thanks to technology. According to Dijk, one of the most striking features of social media is "the obscure distinction between interpersonal and mass communication" (2016: 253). "If in a media platform the sender and the receiver can communicate in the same channel (media) in a participant and interactive way and both can either be in active or passive roles, that media is social media" (Tan, 2017c; Tan, 2017d). Interest in social media can be observed and measured in use and penetration. "According to We Are Social, 3,196 billion people are active social media users. In addition, 2,167 billion people use Facebook and 800 million people use Instagram globally. In Turkey, 51 million people use Facebook and 33 million people use Instagram" (URL-1). Additionally, "In terms of participation to Instagram Turkey holds the second place in the world in terms of the ratio of users to country population, with 33 million users and most users of Instagram are in the 18-29 years interval" (URL-4). This rapid increase in participation in social media results from the fact that social media has interactive, participatory and sharing characteristics, and that people can freely exhibit their selves in social media.

The concept of self is associated with the science of social psychology. Social psychology examines behavioural, emotional and cognitive dimensions of interaction between person and environment, and explains the effects of dimensions with obedience, identification and adoption (Tan, 2019a). Personality is formed through a process which includes a person's sensory organs, the senses they receive through them, the person's process of getting to know, understand and explore self, the person's ideas about their body, how much a person values themselves, how and through what behaviours a person expresses themselves in their communications with themselves and others. Personality is the ability of a person to objectively accept themselves as an object and to look at themselves from the outside. The objective feature is explained objectively as the phenomenon and the ability to look at the events from the outside. Comments and attitude of others come to the fore for the formation of self. It can be observed that people share their own visual images on social media and have access to comments under their shares. The self also wishes to be realized by other selves 
and to dominate them, and to have the upper self. Here, for example, it is not about the capacity of the person to have more image management than others, but rather to the fact that it turns into action and the person wants to gain a superiority over others. Those who know the applications of Instagram that can make changes on the visual and which can make changes on the visual, and who can make design changes on the visuals, gain a superiority to other people about image management. This way it is possible to understand the importance of likes as well as the numerical importance of them. Therefore, the self must exist not only in thought but also in action.

The concept of self is explained as" a person's knowledge, belief and ideas about who and what they are and what traits they possess". Our efforts to create and present self are impression management and self-presentation strategies. Thisendeavours are characterized as "a war of being myself" (Kağıtçıbaşı and Cemalcılar, 2015: 248; Baron and Byrne, 1997: 152; Baron, 1992: 496; Erturk, 2011: 74; Erturk, 2017: 122). The self is related to social structure, social behaviour and social experience. In this way, the self is formed by the process of common attitudes and the person becomes self. Mead, Adler, Maslow, Fromm and Rogers are referred to via their theories on self. According to Rogers (1959) "the self is formed by the thoughts, perceptions and convictions of the individual and the dimensions of the self explain as self image, self-esteem and ideal self" (Güney, 2012: 83; Eroğlu, 2015: 244). When deciding who and what they are, persons they take their decisions both on their own and on the opinions of others. In other words, the person describes their physical, psychographic, social and psychological characteristics. In order to express who and what they are (their own image), the person realizes strategies of impression management and self-presentation in social relations. Symbols, gestures, experiences, subject, our body extensions, other people, objects, memories, awareness and superiority are important for formation, development and nutrition of self. Therefore, the formation of self occurs through the processes of and/or with help of personal adaptation to society, symbols which help the society to form, social experience, others' attitudes towards the person, interaction of the person with the objects in their life and communication.

People satisfy some of their needs with their social relations. Erturk explains this in the following words: "Conditions such as attachment, affection, concern, and uncertainty reduction are a result of this requirement." (...) "The possible consequences of satisfying social relations include satisfying the needs of love and attention, developing the self-concept, approving the image of the self, reducing uncertainty and creating an impression" (2010: 111-240). By joining the social media stage, interacting and sharing, the people both meet the need, develop and present their selves, as well as manage their impressions. Social media is at the same time "a medium/environment where people can portray a more impressing, larger-than-life image of themselves and their lives in an attempt to construct their images" (Çizmeci, 2014; Boyd, 2014). Boyd emphasizes that "people form imagined communities among themselves with their life practices in a space, stage and environment included in networked technologies, which is the core aspect of the concept of 'networked publics' (2014: 8). In his work titled "It's Complicated", Boyd refers to Goffman, stating that people manage their impressions by presenting their selves. Kaplan and Haenlein (2009) emphasize that social media creates a visual social world, which in turn increases the presentation of self. In other words, people make image management on social media platforms.

Social media is also a stage and people present their selves in this stage. The relationship between social media, self and image can be explained in the steps of a) stage, b) merging images, $c$ ) creating self and winning d) managing, e) gaining superiority f) liberation, g) satisfying requirements, $h$ ) creating similarity, I) the myth of pleasure and i) the demonstration of cynicity. The demonstration of cynicism in social media is being investigated in the article titled "digital cynicism" (Tan, 2019a). Social media is a stage that allows people to express their selves, the formation, development and nourishment of the self, and ensures that the self becomes a member of a group to interact with others. In addition, if the ancient Greek theatre combines poetry, music and dance, then social media combines visuals, texts, images (objects), sounds and music in a stage. Using social media people can become aware of, demonstrate, form, gain their selves, see other people's views on them, identify with other people's attributes, go through processes of obedience, identification and adoption in order to communicate with the social structure and the generalized "others", and do image management in order to have superiority over other people. 


\section{Field Theory and Habitus Concept of Pierre Bourdieu}

In his work, Pierre Bourdieu criticizes the dichotomy between phenomenology (subjectivism) and constructivism (objectivism), and Bourdieu wants to synthesize these two approaches, conceptualized in his work, in 'field theory' and 'habitus'. For instance, according to Wacquant, Bourdieu integrates the dichotomy between the two opposing structures and actors in a coherence of economic political, phenomenological approach and structuralist approach. (Bourdieu and Wacquant, 2016: 15). Bourdieu examines the concepts of Habitus and Field, the distinctions between people, positions, practices of positions, and how people are categorized by the struggle in their interaction with others and structures in the social structure. According to Bourdieu, one is neither rational nor mechanically governed. In addition, the person makes strategies with intuition practices. "The education system, the state, the church, the political parties or the unions are not devices but the field" (Bourdieu, 2016: 87). In the context of this research, social media is a microcosm for the person and a macrocosm for power relations. Bourdieu explains the notion of structural conception by explaining that its structuralism is not only within the symbolic system, language and myth emphasized by LevissStrauss and Saussure. According to him "social world itself has objective structures that are capable of guiding and shaping their practices and imaginations independently of their consciousness and will" (Bourdieu, 2016b: 189). According to Bourdieu, the field theory and concept consists of a) social, b) cultural, c) economic, d) symbolic constituents. In the centre of the field there is the concept of "capital". According to Bourdieu, the concept of capital "is a tool or instrument of social distinction" (Yarcı, 2014: 130). Bourdieu explains economic capital as wealth and income; cultural capital as collectible and diploma; social capital with social ties and useful relations; the symbolic capital with prestige, recognition, reputation, knowledge and honour. (Etil and Demir, 2014: 336; Wacquant, 2014a: 447). According to Bourdieu, people are actors and the person is positioned and classified on stage with the social, cultural, economic and symbolic capital that he owns and produces. According to him, "Actors who are classified according to the volume of capital they possess" (...) Social actors define their positions in the structure based on positions which depend on their capitals" (Bourdieu, 2018a; 66-70). Because the research is based on personal image management, Bourdieu's social and symbolic capital concepts are described in the study.

The concept of social capital refers to networks of communication, participation in networks, trust, mutuality, social networks, norms, sense of belonging, mutual recognition and connections. "According to Bourdieu, social capital, social affiliation of social actors, social and cultural codes facilitate social life with the help of facts such as habitus, but on the other hand, they have a function that creates inequalities" (Yarcı, 2014: 125). Social media, where people become members of, do their impression management and present their selves, both facilitates the relations of a person with other people and the structures which contain power relations, and enable individuals to have the ideal, desired self which they desire to impose upon others, therefore creating inequality. In addition, social media is a node of the network society, it is a part of the plane of flows and produces norms of people and power relations with social media. An example of these norms is selfie. Nowadays, it is very popular for people to see themselves and the objects and images they want to identify with. The displayed selfies (the presentation of the self / images) are on the social media pages of the people. Therefore, individuals produce social and symbolic capital by using their social relations, communication networks, smart mobile phones and social media features in social media. According to Bourdieu, "Symbolic capital is the form when any one of the economic, cultural or social capital types pass through the category of perception" (Bourdieu and Wacquant, 2016: 25). In another definition, Bourdieu explains symbolic capital as follows: "it not only consists of social recognition forms and types of perception which constitute known, visible, famous, admired, mentioned, lovable etc. social entities, collectively titled 'theory of privileges', but also of tens of manifestations of charisma which grants the theodicy of existences" (2016a:285). Bourdieu states that the concept of capital is not only of economic nature, "but also it should be expanded to every meta which are deemed rare and worth looking for in a specific social formation, without discriminating between symbolic and material" (2018: 232). And Bourdieu emphasizes that there might be nice words, likes, body language, mimics, gestures, challenges, gossip and dissociation involved. According to Bourdieu, the accumulation of symbolic capital, coding of image (words, text and visuals), symbol and indicators and gathering of these in one tool is possible through manipulation and personal interpretation of coded content by the audience (2018: 196). "Every difference which is recognized and regarded as legitimate works as a symbolic capital which is useful in terms of differentiation" (Bourdieu, 2014a: 198). Bourdieu emphasizes the world of images, creating impression and image 
management. And according to Bourdieu, the symbolic capital "saves the individual -from insignificance, which includes the lack of importance and meaning-" (2016a: 287).

According to Bourdieu, field structures "habitus". "As a system of suitabilities working in practice, habitus is an objective foundation of regular behaviours, that is, the regularity of behaviours" (Bourdieu, 2016b: 127). "To talk about habitus is to demonstrate that what is individual, or even personal and subjective, is of social and collective nature. Habitus is a system of permanent and transferable tendencies/suitabilities in which socialized past experiences are integrated" (Bourdieu, 2015: 234; Bourdieu, 2018: 161). "Habitus gives birth to separate and discriminatory practices (...) Being in a space means being a point, an individual in a space, that is, being different... (Bourdieu, 2015: 22-23). According to Bourdieu, the language created by the habituses and the indicators created by this language serve as a differentiating function. The person fulfils their role as much as their human capital and tendencies allow within the context of "field". In addition, this representation is also the person's position. As Bourdieu emphasizes, meaning is formed within a holistic structure. Naturally "According to Bourdieu (1997: 104), for the operation of an area, there must be people ready for the game, which people should also possess habitus that requires that the game must have inherent rules, targets etc. that should be known beforehand, and these people must have a motive" (Etil and Demir, 2014: 339). In the context of the research, the aim of the young generation and the digital natives to play this game is to create a good impression, a positive and desirable personal image. The person carries out impression and image management using the permanent suitabilities they gained through their past experiences, therefore experiencing the past and the present together. If the subject of the image management is another person, then the individual experiences the present; when the subject utilizes the conditions of the present in tandem with the image management skills they learned from that individual, then they would be living the possible future of a third person who will receive the impression they've created. There are three factors in this stage, namely a) the past, $b$ ) the present, and c) the future. In the process of impression and image management, a person experiences the historical nature of social structures, the stock of historical knowledge and re-lives past experiences. Schütz explains this situation within the context of one's daily life; "the person lives within the stock of knowledge they gain from their experiences" (2018: 87); and Marx remarks as follows: "Men make the history, but they cannot make it exactly as they want, they cannot make it in the conditions they would like, but in those which are encountered first hand, known from and rooted in the past. The tradition of all dead generations collapses like a nightmare on living brains" (Ritzer and Stepnisky, 2014: 47). Schütz and Marx refer to social structures, habitus and the system of suitabilities just like Bourdieu. However, Schütz and Marx also refer to the fact that social structures, habitus and the system of suitabilities form within a historical process. Bourdieu acknowledges that space and habitus are formed in a historical process. But Bourdieu explains that the structure, the field and the habitus are not unchangeable and that they are an open system; "Habitus is not a fate as it is sometimes thought. Since it is the product of history, it is a system of open suitabilities which constantly faces new experiences and are constantly affected by them" (Bourdieu and Wacquant, 2016: 125). Dilthey explains the way out of this as follows;" Here the human being transcends the empty and desolate repetition of nature through consciousness" (2017: 25). In context of the study, new media, communication networks, smart mobile telephones, applications and social media are the stage of new experiences. For people to get past, in Dilthey's words, the empty and desolate repetition, they will need to become aware of the potential to affectmotivate behaviours, form attributes, develop and establish norms, form new lifestyles and do impression and image management, of other people and power relations and they will need to utilize their consciousness for this.

According to Bourdieu, the motives behind a person's formation of capital and gaining a position with it, within the context of the field, are their purposes of "differentiation", "ownership" and "existence". "Existence, which is reduced to ownership, a happening or realization of a possibility, together with habitus, is a requirement for re-creating objective structures, which are outcomes of a collective history, under the forms of permanent suitabilities, and is a product of the seizing work" (Bourdieu, 2018: 176). Bourdieu agrees with Durkheim, saying "Society is God" (Bourdieu, 2016a: 290). Bourdieu describes people as a product of social structures and refers to the creativity of society. 


\section{Method and Research}

The article is written in Istanbul Aydın University under the dissertation titled "Transformation of Personal and Brand Image Management in Social Media". The thesis focuses on transformation of personal and brand image management within the context of personality theory with an extended meaning, which is what is installed in a smartphone by a person to access social media. With the concept of "habits", Bourdieu refers to an earned position, how one gets there, who gets there, habits and processes. In this context, the thesis sets out from the concept of "habitus" in an attempt to explain the relationship between the tool (smartphone) which is used to access social media, social media (the place of settling down) and university students who use social media (settlers), the process which is the outcome of this relationship, and the transformation of the habits which occur as a result of this process in terms of personal and brand image. The thesis employs known communication science methods and applications such as descriptive research, focus group method, survey technic and semiotic analysis. In this article, hypothesis related to transformation of personal image management of research and survey data, findings and results are given.

Hypothesis 1: University students aim to protect and strengthen their self-image and university students want to have the image they desire (self). University students use their social relations to realize this goal.

Hypothesis 2: University students make image management through dramaturgy and impression management in social media channels.

Hypothesis 3: Whether the student's university is a state university or a foundation university is a determinant for how the student uses the social media.

Hypothesis 4: University students use social media because it strengthens their image.

The universe of the research is the university students who are in contact with smartphones that are used to reach social media platforms (Facebook, Instagram). The limitation of the research is the undergraduate, graduate and doctorate students studying communication science in state and foundation universities in Istanbul. The samples of the study are undergraduate, post-graduate and doctorate students at the state universities of Galatasaray University, İstanbul University and Marmara University, and at the foundation universities of İstanbul Aydın University, İstanbul Bahçeşehir University and İstanbul Commerce University. The scale used in the survey of the research belongs to the author of the article, except the questions in the extended self-theory section. While the independent variable of the research is social media usage, dependent variable is personal image management.

The questions in the individual self section aim to analyse a) the impression and image management the person aims to create in the social media page, b) whether the person themselves and other people are aware of the impression and image management that the person is intending to create, c) the person's Smart Mobile Phone which occurs when they edit or add to the visuals which they create during individual image management, as well as whether they make use of social media platforms and applications. In addition, d) the impact of generalized "others" in social media on the person; whether the sets, showcases and decors on the social media stage are made use of, e) the values and achievements the person intends to gain through individual image management in social media are also studied. Research findings were obtained by processing the data acquired from university students in SPSS v25.0 and Amos v23.0 package software programs. The survey data were analysed over the responses received from 845 people. The data acquired was evaluated using percentage and frequency methods. Beside difference analysis, the study also focused on causeeffect relationships. When evaluating research data, in the first stage an explanatory factor analysis regarding scales was carried out in the SPSS program, and then a confirmatory analysis was carried out in the AMOS program. Reliability and difference analyses were implemented according the analysis results acquired. Hierarchical regression analysis was used to study the cause and effect relationship among the variables. Table 1 shows the findings of 845 participants. Among the participants of the survey, $54.4 \%$ of the students were female, $45.6 \%$ were male; $50.5 \%$ were in state universities; $96,1 \%$ of them are undergraduate students in communication faculties. 


\begin{tabular}{|c|c|c|}
\hline Groups & Frequency & Percent \\
\hline \multicolumn{3}{|c|}{ Gender } \\
\hline Woman & 460 & 54.4 \\
\hline Male & 385 & 45.6 \\
\hline \multicolumn{3}{|c|}{ University } \\
\hline Galatasaray University & 62 & 7.3 \\
\hline Istanbul University & 231 & 27.3 \\
\hline Marmara University & 134 & 15.9 \\
\hline $\begin{array}{l}\text { Istanbul Technical } \\
\text { University }\end{array}$ & 151 & 17.9 \\
\hline Bahçeşehir University & 116 & 13.7 \\
\hline $\begin{array}{l}\text { Istanbul Commerce } \\
\text { University }\end{array}$ & 151 & 17.9 \\
\hline \multicolumn{3}{|c|}{$\begin{array}{l}\text { University Type } \\
\end{array}$} \\
\hline State University & 427 & 50.5 \\
\hline Foundation University & 418 & 49.5 \\
\hline
\end{tabular}

Table 1. Characteristics of Research Participants $(n=845)$

Findings regarding internet use of the participant students are demonstrated in Table 2. 25.8\% of the students stated that they spent 3-4 hours daily on the Internet; $24 \%$ stated that they spent $1-2$ hours daily in social media; $54.7 \%$ stated that they frequently use their social media accounts; $39.5 \%$ stated that they publish one post in a month on social media.

The questions, of which the sample size sufficiency were below 0.50, which were the only questions under factors and of which the factor weight was below 0.50 were removed from the analysis. Then the analysis carried out yielded four factors with a proper value of 1 or more. These factors were signified as follows; "brand image", "personal image in social media", "extended self theory" and "the impact of social media shares". The article demonstrates the outcomes of the factors "personal image in social media" and "the impact of social media shares".

\begin{tabular}{|c|c|c|}
\hline $\begin{array}{l}\text { Factor } \\
\text { Name }\end{array}$ & Question Expression & $\begin{array}{c}\text { Factor } \\
\text { Weights }\end{array}$ \\
\hline \multirow{5}{*}{$\begin{array}{l}\text { Social } \\
\text { Media } \\
\text { Personal } \\
\text { Image }\end{array}$} & $\begin{array}{l}\text { I create a positive image on social media against } \\
\text { my friends by sharing visual images (photo / } \\
\text { video / story) about myself on social media. }\end{array}$ & 0.801 \\
\hline & $\begin{array}{l}\text { I think that I am influencing my friends in social } \\
\text { media with my social media shares. }\end{array}$ & 0.760 \\
\hline & $\begin{array}{l}\text { The comments from the content I share with } \\
\text { social media are important to me. }\end{array}$ & 0.670 \\
\hline & $\begin{array}{l}\text { Thanks to social media, my social relations are } \\
\text { developing and strengthening. }\end{array}$ & 0.627 \\
\hline & $\begin{array}{l}\text { Before sharing the images on social media, I edit } \\
\text { images and share them later by taking } \\
\text { advantage of Facebook, Instagram and other } \\
\text { applications. }\end{array}$ & 0.540 \\
\hline \multirow{3}{*}{$\begin{array}{l}\text { Impact of } \\
\text { Social } \\
\text { Media } \\
\text { Shares }\end{array}$} & I see people use social media to impress others. & 0.795 \\
\hline & $\begin{array}{l}\text { By sharing content from entertainment, holidays, } \\
\text { meals, overseas trips, luxury venues and } \\
\text { purchased products, people intend to send } \\
\text { implied messages of superiority to the others. }\end{array}$ & 0.766 \\
\hline & $\begin{array}{l}\text { I see that on social media, people share their } \\
\text { posts in an attempt to direct and manage the } \\
\text { behaviours of other people. }\end{array}$ & 0.611 \\
\hline
\end{tabular}

Table 2. Aspects of Internet Use ( $n=845$ 


\begin{tabular}{|c|c|c|}
\hline Groups & $\begin{array}{c}\text { Frequenc } \\
y\end{array}$ & Percent \\
\hline \multicolumn{3}{|c|}{ Daily Average Internet Usage } \\
\hline None & 16 & 1.9 \\
\hline $0-1$ hours & 27 & 3.2 \\
\hline $1-2$ hours & 103 & 12.2 \\
\hline $2-3$ hours & 194 & 23.0 \\
\hline $3-4$ hours & 218 & 25.8 \\
\hline 4-6 hours & 206 & 24.4 \\
\hline 8 hours and above & 81 & 9.6 \\
\hline \multicolumn{3}{|c|}{ Daily Average Social Media Usage } \\
\hline None & 40 & 4.7 \\
\hline $0-1$ hours & 106 & 12.5 \\
\hline $1-2$ hours & 203 & 24.0 \\
\hline $2-3$ hours & 165 & 19.5 \\
\hline 3-4 hours & 155 & 18.3 \\
\hline $4-6$ hours & 127 & 15.0 \\
\hline 8 hours and above & 49 & 5.8 \\
\hline \multicolumn{3}{|c|}{ Daily Use of Social Media Accounts } \\
\hline Very intensely & 141 & 16.7 \\
\hline Often & 462 & 54.7 \\
\hline Sometimes & 152 & 18.0 \\
\hline Rarely & 35 & 4.1 \\
\hline $\begin{array}{l}\text { I don't use it every } \\
\text { day }\end{array}$ & 55 & 6.5 \\
\hline \multicolumn{3}{|c|}{ Sharing from Social Media Accounts } \\
\hline 5 every day & 16 & 1.9 \\
\hline 3 every day & 32 & 3.8 \\
\hline 1 every day & 50 & 5.9 \\
\hline 3 per week & 72 & 8.5 \\
\hline 1 weekly & 230 & 27.2 \\
\hline 1 monthly & 334 & 39.5 \\
\hline Never & 111 & 13.1 \\
\hline
\end{tabular}

Table 3. Explanatory Factor Analysis

According to the results obtained as per personal image on social media, presented in Table 3 , university students share positive images in social media platforms in order to create positive images and in doing so, they believe that they impress their friends. The gestures, gestures, body language, likes and rumours in the images can be deemed as a meta production in terms of Bourdieu's view, which is in other words, a production of symbolic capital. In addition, the young generation is using symbolic capital while also employing their social capital.

One is motivated by a goal in the production of symbolic capital, and the purpose of the person is to differentiate themselves by having a positive image by influencing the behaviour of others through the social media stage. And people are positioned according to the images they share in the social media, the number of friends they have and the numerical magnitude of the likes. In order to enhance their position, people need to produce more symbolic capital, have others in the social media stage like the images of them and follow their page. This refers to Bourdieu's concept of symbolic power that is "The power over others, which is drawn from the existence, views, perceptions and appreciations of others". In order for the person to increase their capital, they need to increase the number of their followers and the likes coming in on the images that they share. To achieve this, the person needs the social media stage, social media applications, as well as the features of the smartphone which they use to access social media. According to the results of the research, before sharing the images on social media, people edit their images by making use of Facebook, Instagram and other applications and then share their images. University students accept that they do impression and image management in the social media stage. The personal impression and image management, which is the knowledge stock from the past, as iterated in the descriptive section of the research, is 
utilized by people in the social media stage. But this knowledge stock is transformed by the habitus, technology, new media, social media and digital code, in the words of Bourdieu. Thanks to the capabilities of the digital code, university students can change their images, as well as edit and transform the images they want to share. In addition, according to the findings of the research, the young generation states that "their social relationships are developing and strengthening thanks to social media". The young generation is also referring to the fact that social media increases their social capital by emphasizing their social ties through social media. According to the findings and interpretations of the study, the first and second hypotheses are verified.

According to the results of the explanatory factor analysis for the impact of social media shares in Table 3, university students are aware that people aim to manage other people using their social media shares; people use social media to impress other people; and people aim to gain superiority over others using denotations and connotations in the images in their social media posts. As emphasized in the descriptive part of this study, people can make choices with the consciousness they have and can combine, interpret, compare and evaluate the meanings of images, symbols and indicators. While the self makes the impression and image management in order to gain the image it desires, the consciousness can realize the practices of impression and image management of both itself and the other and combines, interprets, compares and evaluates these practices, events and phenomena. Through the consciousness of the person, one realizes the difference between impression and image management of others and also understands, evaluates and interprets how he can increase social capital and symbolic in the social media stage. Thus, as Bourdieu emphasized in his words "Being in a space, a point in a space, being an individual means differentiation" a person also learns how to position themselves, differentiate and exist in the stage (space) of social media.

\begin{tabular}{|c|c|c|c|c|c|c|c|}
\hline Variables & Gender & $\mathbf{N}$ & $\bar{X}$ & $\begin{array}{l}\text { Std. } \\
\text { Dev. }\end{array}$ & $\bar{F}$ & $\mathbf{t}$ & $\mathbf{P}$ \\
\hline \multirow{2}{*}{$\begin{array}{l}\text { Social Media } \\
\text { Personal Image }\end{array}$} & Female & 460 & 3.3422 & 0.77446 & \multirow{2}{*}{8.919} & \multirow{2}{*}{2.830} & \multirow{2}{*}{0.005} \\
\hline & Male & 385 & 3.1756 & 0.91226 & & & \\
\hline \multirow{2}{*}{$\begin{array}{l}\text { Impact of Social } \\
\text { Media Shares }\end{array}$} & Female & 460 & 3.9319 & 0.71108 & \multirow{2}{*}{6.438} & \multirow{2}{*}{1.506} & \multirow{2}{*}{0.132} \\
\hline & Male & 385 & 3.8528 & 0.79875 & & & \\
\hline
\end{tabular}

Table 4. Gender Analysis $(n=845)$

When the research findings in Table 4 are examined, it was determined that social media personal image levels of women are higher than men.

According to Table 5, there is a statistically significant difference between the impact of social media personal image and social media share and university type $(p<0.05)$. When the findings are examined, it is determined that the foundation university students' levels of personal image of social media are higher than those of the students of the state university. In addition, the impact of social media shares of students in public universities is higher than that of the students studying at foundation universities. According to the results of the study, the third hypothesis of research, which is "being a student at a state or a foundation university affects the use of the student's social media use" is confirmed.

\begin{tabular}{|c|c|c|c|c|c|c|c|}
\hline Variables & Uni. Type. & $\mathbf{N}$ & $\bar{X}$ & Std. Dev. & $F$ & $t$ & $\mathbf{P}$ \\
\hline \multirow{2}{*}{$\begin{array}{l}\text { Social Media } \\
\text { Personal } \\
\text { Image }\end{array}$} & State & 427 & 3.1813 & 0.86791 & \multirow{2}{*}{1.200} & \multirow{2}{*}{-2.974} & \multirow{2}{*}{0.003} \\
\hline & Foundation & 418 & 3.3531 & 0.80995 & & & \\
\hline \multirow{2}{*}{$\begin{array}{l}\text { Impact of } \\
\text { Social Media } \\
\text { Shares }\end{array}$} & State & 427 & 3.9672 & 0.75920 & \multirow{2}{*}{0.383} & \multirow{2}{*}{2.796} & \multirow{2}{*}{0.005} \\
\hline & Foundation & 418 & 3.8230 & 0.74017 & & & \\
\hline
\end{tabular}

Table 5. Differential Analysis by University Type $(n=845)$ 
According to the results of the analysis in Table 6:

a) Social media personal image levels of the students who daily use internet between 3 and 4 hours on average are higher than those of the students who do for 1 to 2 hours ( $p$ $<0.05)$.

b) Social media personal image levels of the students who daily use internet between 3 and 4 hours on average are higher than those of the students who do for 2 to 3 hours ( $p$ $<0.05$ ).

c) Social media personal image levels of the students who daily use internet between 4 and 6 hours on average are higher than those of the students who do for 1 to 2 hours ( $p$ $<0.05)$.

According to Table 6 , there is a positive relationship between personal image levels and how much more people use the Internet.

\begin{tabular}{|c|c|c|c|c|c|}
\hline Variable & $\begin{array}{l}\text { G. Int. } \\
\text { (I) }\end{array}$ & $\begin{array}{l}\text { G. Int. } \\
\text { (J) }\end{array}$ & $\begin{array}{c}\text { Average } \\
\text { Difference } \\
(\mathrm{I}-\mathrm{J})\end{array}$ & $\begin{array}{l}\text { Standard } \\
\text { Error }\end{array}$ & $\begin{array}{c}\text { Significance } \\
\text { Level }\end{array}$ \\
\hline \multirow{3}{*}{$\begin{array}{l}\text { Social Media } \\
\text { Personal } \\
\text { Image }\end{array}$} & \multirow{2}{*}{$3-4$} & $1-2$ & $0.38948^{*}$ & 0.09763 & 0.002 \\
\hline & & $2-3$ & $0.25292^{*}$ & 0.07763 & 0.025 \\
\hline & $4-6$ & $1-2$ & $0.36990^{*}$ & 0.09984 & 0.006 \\
\hline \multirow{5}{*}{$\begin{array}{l}\text { Impact of } \\
\text { Social Media } \\
\text { Shares }\end{array}$} & \multirow{5}{*}{ None } & $1-2$ & $-0.68507^{*}$ & 0.19912 & 0.011 \\
\hline & & $2-3$ & $-0.86362^{*}$ & 0.19274 & .000 \\
\hline & & $3-4$ & $-0.88704^{*}$ & 0.19193 & 0.000 \\
\hline & & $4-6$ & $-0.89381^{*}$ & 0.19231 & 0.000 \\
\hline & & $8+$ & $-0.92104^{*}$ & 0.20273 & 0.000 \\
\hline
\end{tabular}

Table 6. Tukey and Tamhane T2 Test Results for Daily Internet Use Times

\begin{tabular}{|c|c|c|c|c|c|}
\hline Variable & $\begin{array}{l}\text { Sos. Med. } \\
\text { (I) }\end{array}$ & $\begin{array}{l}\text { Sos. Med. } \\
\text { (J) }\end{array}$ & $\begin{array}{c}\text { Average } \\
\text { Difference } \\
(\mathrm{I}-\mathrm{J})\end{array}$ & $\begin{array}{l}\text { Standard } \\
\text { Error }\end{array}$ & $\begin{array}{l}\text { Significance } \\
\text { Level }\end{array}$ \\
\hline \multirow{11}{*}{$\begin{array}{l}\text { Social Media } \\
\text { Personal } \\
\text { Image }\end{array}$} & \multirow{4}{*}{ None } & $2-3$ & $-0.71182^{*}$ & 0.16520 & 0.002 \\
\hline & & $3-4$ & $-0.74161^{*}$ & 0.16607 & 0.001 \\
\hline & & $4-6$ & $-0.92150^{*}$ & 0.17203 & 0.000 \\
\hline & & $8+$ & $-0.77163^{*}$ & 0.20537 & 0.007 \\
\hline & \multirow{4}{*}{$0-1$} & $2-3$ & $-0.64635^{*}$ & 0.10374 & 0.000 \\
\hline & & $3-4$ & $-0.67614^{*}$ & 0.10513 & 0.000 \\
\hline & & $4-6$ & $-0.85602^{*}$ & 0.11430 & 0.000 \\
\hline & & $8+$ & $-0.70616^{*}$ & 0.16016 & 0.001 \\
\hline & \multirow{3}{*}{$1-2$} & $2-3$ & $-0.33807^{*}$ & 0.07711 & 0.000 \\
\hline & & $3-4$ & $-0.36787^{*}$ & 0.07897 & 0.000 \\
\hline & & $4-6$ & $-0.54775^{*}$ & 0.09082 & 0.000 \\
\hline \multirow{4}{*}{$\begin{array}{l}\text { Social Media } \\
\text { Shares' } \\
\text { Impact }\end{array}$} & \multirow{4}{*}{ None } & $0-1$ & $-0.43899^{*}$ & 0.13867 & 0.027 \\
\hline & & $2-3$ & $-0.47677^{*}$ & 0.13170 & 0.006 \\
\hline & & $3-4$ & $-0.50968^{*}$ & 0.13253 & 0.002 \\
\hline & & $4-6$ & $-0.50446^{*}$ & 0.13549 & 0.004 \\
\hline
\end{tabular}

Table 7. Tukey and Tamhane T2 Test Results for Daily Social Media Use Times

According to the results of the analysis in Table 7:

a) The social media personal image levels of the students who are not present in social media are lower than those who use social media for 2-3, 3-4, 4-6 and 8 hours $(p<0.05)$.

b) The social media personal image levels of the students who are present in social media for 0-1 hours daily are lower than those who use social media for 2-3, 3-4, 4-6 and 8 hours $(p<0.05)$.

c) The social media personal image levels of the students who are present in social media for 1-2 hours daily are lower than those who use social media for 2-3, 3-4 and 4-6 hours $(p<0.05)$. 
According to the results of the analysis, using social media more affects the personal image level of the individuals. By using social media, the younger generation desires to increase both their social and symbolic capitals.

According to Table 8, the results of the analysis, the following findings were obtained:

- $\quad$ Social media personal image levels of the students who very intensively use social media are higher than those of the students who frequently, sometimes, rarely or very rarely use social media $(p<0.05)$.

- $\quad$ The impact levels of social media shares of the students who very intensively use social media are higher than those of the students who frequently, sometimes or very rarely use social media $(p<0.05)$.

- $\quad$ Social media personal image levels of the students who frequently use social media are higher than those of the students who rarely or very rarely use social media $(p<0.05)$.

- $\quad$ Social media personal image levels of the students who frequently use social media are higher than those of the students who sometimes use social media $(p<0.05)$.

\begin{tabular}{|c|c|c|c|c|c|}
\hline Variable & $\begin{array}{l}\text { S. Med. } \\
\text { (I) }\end{array}$ & $\begin{array}{l}\text { S. Med. } \\
\text { (J) }\end{array}$ & $\begin{array}{c}\text { Average } \\
\text { Difference } \\
(\mathrm{I}-\mathrm{J})\end{array}$ & $\begin{array}{c}\text { Standard } \\
\text { Error }\end{array}$ & $\begin{array}{c}\text { Significance } \\
\text { Level }\end{array}$ \\
\hline \multirow{7}{*}{$\begin{array}{l}\text { Social } \\
\text { Media } \\
\text { Personal } \\
\text { Image }\end{array}$} & \multirow{4}{*}{$\begin{array}{c}\text { Very } \\
\text { Intensively }\end{array}$} & Often & $0.39975^{*}$ & 0.07176 & 0.000 \\
\hline & & Sometimes & $0.80866^{*}$ & 0.09288 & 0.000 \\
\hline & & Rarely & $1.27603^{*}$ & 0.16760 & 0.000 \\
\hline & & $\begin{array}{l}\text { I don't use } \\
\text { it every } \\
\text { day }\end{array}$ & $1.11966^{*}$ & 0.14146 & 0.000 \\
\hline & \multirow[b]{3}{*}{ Often } & Sometimes & $0.40891^{*}$ & 0.07588 & 0.000 \\
\hline & & Rarely & $0.87628^{*}$ & 0.15881 & 0.000 \\
\hline & & $\begin{array}{l}\text { I don't use } \\
\text { it every } \\
\text { day }\end{array}$ & $0.71991^{*}$ & 0.13093 & 0.000 \\
\hline \multirow{3}{*}{$\begin{array}{l}\text { Impact } \\
\text { of Social } \\
\text { Media } \\
\text { Shares }\end{array}$} & \multirow{3}{*}{$\begin{array}{c}\text { Very } \\
\text { Intensively }\end{array}$} & Often & $0.21028^{*}$ & 0.06453 & 0.013 \\
\hline & & Sometimes & $0.31691^{*}$ & 0.08402 & 0.002 \\
\hline & & $\begin{array}{l}\text { I don't use } \\
\text { it every } \\
\text { day }\end{array}$ & $0.44578^{*}$ & 0.14636 & 0.032 \\
\hline
\end{tabular}

Table 8. Tukey and Tamhane T2 Test Results for Using Social Media

According to Table 8 , there is a positive relationship between the intense social media use and personal image levels of the younger generation. In addition, there is a positive relationship between the younger generation's use of social media and the impact level of their social media shares. The young generation, in other words, digital natives, both increase their social and symbolic capital in the social media stage, while increasing awareness of others about behaviours, sharing and social and symbolic capital production. According to the results of the research on younger generations, these individuals edit their visuals before sharing them, using the features provided by Facebook and Instagram. Visual, auditory and conceptual images, which exist thanks to digital code, which combines, and at the same time converges, communication networks, media and information technologies, may cease to exist due to the activities of gatekeepers. In this case, the extent of reality in the shared images will inevitably reduce. The younger generation can also have a virtual image in the online space (stage).

\section{Conclusion}

Social media is a stage in the context of this research, and the younger generation produces both social and symbolic capitals in this stage, which positions them in this space according to the capital they are able to produce. People use stock of past knowledge to produce meta (images and content) to share on the social media stage. People utilize the historical stock of knowledge for their 
personal image management, apply this knowledge in the present and by doing this, they shape the future personalities and images of the others, whom they share the social media stage with. There is also a temporal association in this relationship. In fact, past, present and future are all happening at the same time. Social media is a stage which enables people to form, develop, nurture their personalities, and gain awareness and establish superiority to other people. The data, findings and comments of this research also confirm this information. According to the results of the research, people desire to become noticed on the social media stage so they do personal impression management; attempt to establish superiority over other people by altering, transforming and adding to their visuals; and therefore, gain an upper self in this stage. Also, the other people's comments, attributes, stances, gestures and mimics of other people towards them is important for social media users. In addition, people need the views, comments, attributes and likes of other people in the social media stage so they can gain symbolic power in the social media stage. A person's attachment to and dependence on the persons and groups also vary according to their ideas about social media use, the length of their history of social media use and their purpose of using social media. Additionally, social media helps its users to form, gain, develop and present their personalities.

In a system of suitabilities which form on the stage of social media, people carry out personal impression and image management which they naturally practice in their daily lives. This impression and image management is different from the personal impression and image management that is also present in everyday life practices, in that it happens online (space and stage). By using the features of social media tools and their smartphones, which they use to access social media, people are able to extract images from and add images to their own images. Underlying this effort of people is people's desires to increase the levels of their social and symbolic capitals, and therefore gain a positive, appealing and ideal image online. According to Bourdieu, therefore, the person wants to" differentiate", "own" and "exist". One needs to produce symbolic capital in order to "differentiate", "own" and "exist". Because "symbolic capital saves the person from insignificance - which both expresses the lack of importance and meaning ". A person is a "being" which is rooted on the constituents of space and is reduced to the capitals they have. A person struggles to obtain a position within a system of suitabilities which form in the stock of historical knowledge, experience, tradition and norms. The system of suitabilities, which is connected to personal image management and presentation of self in social media, is being transformed today by technology. Thanks to this transformation of the habitus, people can more easily produce and increase their social and symbolic capitals. People can be positioned on the social media stage according to their social and symbolic capital. The people who are followed by millions of people in the social media stage, receive many likes and much interaction to the content that they share are named "influences", "icons" and "famous". Using their social and symbolic capitals that they produce on the stage of social media, people can exist both in the microcosm and the macrocosm. In other words, striving in the fields and habituses in the societies they live, people can exist both at national and global scales. When saying Society is God, Bourdieu underlines that people can only exist based on the constituents of their social field and as long as they utilize habituses. A suggestion with the research is to study the relationship between social media and economic and cultural capitals.

\section{References}

[1] Akgöz, B. E. (2014). İmaj Perspektifinden Kurum Liderleri, ed. Aydınalp, G. I. İmaj Üretimi, Ankara: Nobel Akademik Publishing. p:17-30.

[2] Arnheim, R. (2015). Görsel Düşünme, çev: Öğdül, R. İstanbul: Metis Publishing.

[3] Baron, R. A. (1992). Psychology, Allyn \& Bacon A Division of Simon \& Schuster, Inc. Printed in the United States of America.

[4] Baron, A. B. \& Byrne D. (1997). Social Psychology, A Viacom Company, Printed in the United States of America.

[5] Barthes, R. (2016). Göstergeler Imparatorluğu, çev: Yücel, T. İstanbul: Yapı Kredi Kültür Sanat Publishing.

[6] Bourdieu, P. (2014a). Simgesel Sermaye ve Toplumsal Sınıflar, çev: Ökten, N. Pierre Bourdieu, İstanbul: Yapı Kredi Publishing, Sayı: 76, p: 192- 203.

[7] Bourdieu, P. (2014b). Insanlar ve Mekanizmalar, çev: Tatlıcan, Ü., Pierre Bourdieu, İstanbul: Yapı Kredi Publishing, Sayı: 76, p: 432- 443. 
[8] Bourdieu, P. (2015). Pratik Nedenler: Eylem Kuramı Üzerine, çev: Tanrı̈ver, H. U. İstanbul: Hil Yayın.

[9] Bourdieu, P. \& Passeron, J-C. (2015a). Yeniden Üretim: Eğitim Sistemine İlişkin Bir Teorinin İlkeleri çev: Sümer, A. Ünsaldı, L. \& Akkaya, Ö. Ankara: Heretik Basım Yayın.

[10] Bourdieu, P. \& Wacquant, L. (2016). Düşünümsel Bir Antropoloji İçin Cevaplar, çev: Ökten, N. İstanbul: İletişim Publishing.

[11] Bourdieu, P. (2016a). Akademik Aklın Eleştirisi: Paskalca Düşünme Çabaları, çev: Yalım, P. B. İstanbul: Metis Publishing.

[12] Bourdieu, P. (2016b). Seçilmiş Metinler, çev: Ünsaldı, L. Ankara: Heretik Publishing.

[13] Bourdieu, P. (2017). Ayrım: Beğeni Yargısının Toplumsal Eleştirisi, çev: Şannan, D.\&Berkkurt, A. Ankara: Heretik Basın Yayın.

[14] Bourdieu, P. (2018). Bir Pratik Teorisi İçin Taslak; Kabiliye Üzerine Üç Etnoloji Çalışması, çev: Ökten, N. İstanbul: İstanbul Bilgi Üniversitesi Publishing.

[15] Bourdieu, P. (2018a). Bilimsel Toplumsal Kullanımları: Bilimsel Alanın Klinik Bir Sosyolojisi İçin, çev: Ünsaldı, L. Ankara: Heretik Basın Yayın.

[16] Boyd, D. (2014). It's Complicated: The Social Lives of Networked Teens, Yale University, New Haven, London,

[17] Bulduklu, Y. (2015). Imaj Yönetimi, Yaklaşımlar, Taktikler, Stratejiler, Konya: Seba Ofset Matbaacılık, Literatürk Academia,

[18] Çakır, Ö. (2015). Profesyonel Yaşamda Kişisel İmaj ve Sosyal Yaşam Etiketi, İstanbul: Yapı Kredi Publishing.

[19] Çizmeci, E. (2014). Danah Bod'da Sosyal Ağlar ve Gençlik, M. Yeni Medyaya Eleştirel Yaklaşımlar, İstanbul: Doğu Kitabevi, p: 385-411.

[20] Dijk, J. V. (2016). Ağ Toplumu, çev: Sakin, Ö. İstanbul: Epsilon Publishing.

[21] Dilthey, W. (2017). Hermeneutik ve Tin Bilimleri, çev: Özlem, D. İstanbul: Notos Kitap Publishing.

[22] Dinçer, M, K. (2001). Kişisel İmaj: İş Yaşamında ve Özel Yaşamda, İstanbul: Alfa Basım Yayım.

[23] Eroğlu, Y. (2015). Benlik Kurgusu, ed. Akın, A. \& Akın, Ü. Psikolojide Güncel Kavramlar 2: Benlik, Ankara: Nobel Akademik Publishing, p:243-260.

[24] Etil, H. \& Demir, M. (2014). Pierre Bourdieu'nün Bilim Sosyolojisine Katkısı: "Alan Teorisi", "Habitus", Cini ve "Refleksivite Talebi", Pierre Bourdieu, İstanbul: Yapı Kredi Publishing, Sayı: 76, p: 312- 349.

[25] Fromm, E. (2015). Rüyalar Masallar Mitler, çev: Arıtan, A. ve Ökten, K. İstanbul: Say Publishing. (Özgün adı: The Forgotten Language. An Introduction to the Understanding of Dreams Fairy Tales and Myths).

[26] Goffman, E. (1978). The Presentation of Self in Everyday Life, Penguin Books Ltd. Made and printed in Great Britain by Cox \& Wyman Ltd, London. Goffman, E. (2014). Günlük Yaşamda Benliğin Sunumu, çev: Cezar, B. İstanbul: Metis Publishing.

[27] Gombrich, E. H. (2015), Imge Ve Göz, çev: Atakay, K. İstanbul: Yapı Kredi Publishing. (Orginal title: The Image and the Eye, 1982, Phaidon Press Limited)

[28] Güney, S. (2012). Sosyal Psikoloji, Ankara: Nobel Akademik Publishing.

[29] Güngör, N. (2013). Iletişim Kuramlar ve Yaklaşımlar, Ankara: Ekinoks Yayın Dağııım.

[30] Hinton, S. \& Hjorth L. (2013). Understanding Social Media, Sage Publications Ltd. Printed and bound by CPI Group (UK) Ltd.

[31] Jenkins, H. \& Ford, S. \& Green, J. (2013). Spreadable Media: Creating Value And Meaning In A Networked Culture, New York University Press, New York and London. Manufactured in the United States of America.

[32] Kabadayı, S. (2018). 10 Adımda Kişisel İmaj, Ankara: Elma Yayınevi.

[33] Kağıtçıbaşı, Ç. \& Cemalcılar, Z. (2015). Dünden Bugüne Insan ve Insanlar, Sosyal Psikolojiye Giriş, İstanbul: Evrim Yayınevi.

[34] Kaplan, A, M. \& Hanlein, M. (2009). Users Of The World, Unite! The Challenges and Oppurtinities Of Social Media. Kelley School Of Business, Indiana University, pp: 59-68. 
[35] Kotler, P. \& Armstrong, G. (2016). Principles of Marketing, Pearson Education Limited, England.

[36] Mangold, W, G. \& Faulds, D, J. (2009). Social Media: The New Hybrid Element Of The Promotion Mix. Kelley School Of Business, Indiana University, pp:357-365.

[37] Mattelart, A. (2004). Bilgi Toplumunun Tarihi, çev: Altınel, H. Y. İstanbul: Iletişim Publishing.

[38] Mitchell, W. J. T. (2005). Imaj, Metin, Ideoloji, çev: Arslan, H. İstanbul: Paradigma Publishing.

[39] Okay, A. (2012). Kurum Kimliği, İstanbul: Derin Publishing.

[40] Özdemirci, A. (2012). Popüler Kültür, Tüketim Psikolojisi ve Imaj Yönetimi: Türkiye (19501980), İstanbul: Beta Publishing.

[41] Polat, S. \& Arslan, Y. (2015). Örgütsel Yaşamda Imaj: Imaj Geliştirme ve Yöntemi, Ankara: Nobel Akademik Publishing.

[42] Reynaud, J, D. \& Bourdieu, P. (2014). Bir Eylem Sosyolojisi Mümkün müdür?, çev: Tatlıcan, Ü., Pierre Bourdieu, İstanbul: Yapı Kredi Publishing, Sayı: 76, p: 140- 151.

[43] Ritzer, G. \& Stepnisky, J. (2014). Sosyoloji Kuramları, çev: Hülür, H. Ankara: De Ki Basım Yayım.

[44] Sampson, E. (1995). Imaj Faktörü, çev: İlgün, H. İstanbul: Rota Yayın.

[45] Schütz, A. (2017). Fenomenoloji ve Toplumsal İlişkiler, çev: Akan, A. \& Kesikoğlu, S. Ankara: Heretik Publishing.

[46] Tan, H. (2017a). Itibar Kavramında Reklamın Önemi ve Reklamın Marka Dünyasına Etkisi, İstanbul Aydın Üniversitesi Dergisi, Nisan, Vol. 9. p:1-23.

DOI.10.17932/IAUD.13091352.2017.9/34.1-23. dergipark.gov.tr/iaud/35220/390727

[47] Tan, H. (2017b). Pazarlama İletişiminin Tarihsel Gelişimi ve Üniversite Öğrencilerinin Sosyal Medyadaki Pazarlama İletişimi Uygulamalarına Bakışını Sormaca ve Fokus Tekniği Yöntemi Ille İncelemek, ed. Yengin, D. İletişim Çalışmalarında Araştırma Yöntemleri ve Uygulamaları, İstanbul: Der Publishing, p:115-157.

[48] Tan, H. (2017c). Pazarlama Amaçlı Halkla İlişkilerin Sosyal Medyadaki Uygulamalarını Starbucks Markası Üzerinden İncelemek, 2. Genç Bilim İnsanları Sempozyumu, İstanbul: İstanbul Aydın Üniversitesi Publishing, p:119-135.

[49] Tan, H. (2017d). To Examine Reasons Of Social Media Usage Through Personal And Brand Image Management, Communication and Technology Congress-CTC 2017, İstanbul Aydin University, DOI:10.7456/ctc_2017_08. Pp: 105-115. Web of Science. Publiser; Editografica SRL, INTL Proceedingf Div, Via G Verdi 15, Pianoro, Bologna 1-40065, İtaly.

[50] Tan, H. (2019a). "Dijital Kinizm”, Dijital Hastalıklar, Ed: Karadağ, G, H. İstanbul: Der Kitabevi ve Yayınevi, p: 191-225.

[51] Wacquant, L. (2014). Simgesel İktidar ve Grup Oluşumu: Pierre Bourdieu'nün Sınıfı Yeniden Çerçevelemesi Üzerine, çev: Ünal, E. . Pierre Bourdieu, İstanbul: Yapı Kredi Publishing, Sayı: 76, p: 204- 229.

[52] Wacquant, L. (2014a). Bourdieu'yle Birlikte: Loic Wacquant'la Söyleşi. Pierre Bourdieu, İstanbul: Yapı Kredi Publishing, Sayı: 76, p: 445- 450.

[53] Yarcı, S. (2014). Pierre Bourdieu'da sosyal sermaye kavramı. Akademik İncelemeler Dergisi (AID), 6 (1), 125-135. Retrieved from

http://dergipark.gov.tr/akademikincelemeler/issue/1549/19031.

[54] URL-1: www.slideshare.net/wearesocial/digital-in-2018-global-overview-86860338 (Erişim Tarihi: 15.03.2018).

[55] URL-2 : http://www.cumhuriyet.com.tr/haber/teknoloji/914549 (Erişim Tarihi: 15.03.2018). 